\title{
Inhibition of matrix metalloproteinase-2 secretion by chalcones from the twigs of Dorstenia barteri Bureau
}

\author{
Bathelemy Ngameni $^{\mathrm{a}, \mathrm{b}}$, Mohamed Touaibia ${ }^{\mathrm{a}}$, Anissa Belkaid ${ }^{\mathrm{c}}$, Pantaleon Ambassa ${ }^{\mathrm{b}}$, \\ Jean Watchueng ${ }^{b}$, Ramesh Patnam ${ }^{a}$, Bonaventure T. Ngadjuib ${ }^{b}$ Borhane Annabi, \\ and René $\operatorname{Roy}^{\mathrm{a}}$ * \\ ${ }^{a}$ Department of Chemistry, Université du Québec à Montréal, P.O. Box 8888, Succ. Centre-Ville, \\ Montreal, Quebec, Canada \\ ${ }^{b}$ Department of Organic Chemistry, Université de Yaoundé-1, B.P. 812, Yaoundé, Cameroun \\ ${ }^{c}$ Laboratory of Molecular Oncology, Department of Chemistry, Centre BioMed, Université du \\ Québec à Montréal, Montreal, Quebec, Canada \\ E-mail: roy.rene@uqam.ca
}

\section{Dedicated to Professor Berhanu M. Abegaz on the occasion of his 60th birthday}

\begin{abstract}
Chalcones and their analogs were extracted from the twigs of Dorstenia barteri and investigated for their capacity to inhibit matrix metalloproteinase (MMP)-2 secretion from brain tumorderived U87 glioblastoma cells. Among all tested compounds, potent inhibitory activities were recorded for chalcones $\mathbf{1}, \mathbf{4}, \mathbf{5}$, and $\mathbf{6}$ and to a lesser extent for $\mathbf{2}$ and 3. Semi-synthetic derivatives 7-9 displayed low $(<30 \%)$ MMP-2 secretion inhibitory activity at concentrations ranging from 0.025 to $250 \mu \mathrm{M}$. Chalcones $\mathbf{1}, \mathbf{4}, \mathbf{5}$, and $\mathbf{6}$ were found to be more active in comparison to the documented MMP secretion inhibitors chlorogenic acid (CHL) and epigallocatechin-3-gallate (EGCg). Hydrogenation of $\mathbf{1}$ and acid-catalyzed cyclization of $\mathbf{3}$ were performed, thus generating three semi-synthetic derivatives (7-9). The newly synthesized flavanone 7 (cycloglabrol) and its chalcone analog 8 (isocycloglabrol) exhibited low MMP-2 secretion inhibitory activity with $30 \%$ inhibition at $250 \mu \mathrm{M}$. The activity of Dorstenia barteri crude extracts could be attributable to the high concentration of prenylated chalcones and more specifically to stipulin 5. Altogether, the structure-activity relationships established indicated that the hydroxyl, 2,3-double bond, the prenyl group, and its positioning could account for their role in inhibiting MMP-2 secretion, a process involved in extracellular matrix degradation and brain tumor progression.
\end{abstract}

Keywords: Dorstenia barteri, chalcones, (-)-epigallocatechin-3-gallate, chlorogenic acid metalloproteinase, glioblastoma 


\section{Introduction}

It is well established that natural products constitute excellent sources of phytochemicals having a wide range of biological activities, including anticancer properties. ${ }^{1}$ In the search for new antitumoral agents; several plant extracts have been investigated. This has opened new fields of investigations toward potential antitumor agents, some of which are already widely used in cancer chemotherapy. ${ }^{2}$ Flavonoids, a group of polyphenolic secondary metabolites present in a wide variety of plants, have been reported to display a large panel of biochemical properties, including antioxidant activity, inhibition of tyrosine kinases, cAMP phosphodiesterases, and induction of phase II metabolizing enzymes both in vivo and in vitro. ${ }^{3}$ These biological activities, have also been associated with their capacity to control cell growth or destroy pathogen organisms, such as fungi and viruses. ${ }^{4,5}$ Several prenylated (3-methylbut-2-enylated) flavonoids have shown interesting cytotoxic and/or antitumor properties, including flavones, ${ }^{6}$ flavanones, ${ }^{7}$ and chalcones. ${ }^{7,8}$ The cytotoxic activity of prenylated flavonoids have been reported and their structure-activity relationships discussed. ${ }^{7,9}$ However, from the compiled information on chalcones, it can be deduced that the presence of $\alpha, \beta$-conjugated double bonds, the hydroxyl groups at $\mathrm{C}_{2^{\prime}}$ and $\mathrm{C}_{4^{\prime}}$ in ring $\mathrm{A}$, and at $\mathrm{C}_{4}$ of ring $\mathrm{B}$, appear to be important for enhanced activity. Alternatively, little is known about the influence of substituents at other positions and their roles are not clear. Flavonoids, particularly 4-hydroxylonchocarpin (2) isolated from D. mannii, ${ }^{10}$ are good chemopreventive molecules against ovarian cancer cell growth. ${ }^{11}$ Recently, isobavachalcone (1) and dorsmannin A (6) isolated from D. barteri Bureau ${ }^{12}$ and D. mannii, ${ }^{10}$ exhibited inhibitory effects on skin tumor promotion in an in vivo two-stage mouse skin carcinogenesis test. ${ }^{13}$

As part of a screening program on active ingredients isolated from Dorstenia species and other natural products having antitumor properties, the aim of the present investigation is to explore the potential inhibitory effect of chalcones isolated from the twigs of $D$. barteri var. multiradiata and of their semisynthetic analogs on matrix metalloproteinase (MMP)-2 secretion in the highly invasive human brain tumor-derived glioblastoma cell line U87. The inhibitory effects were compared to those of the phenolic compounds CHL and EGCg, both documented for their potential to inhibit MMP secretion. ${ }^{14,15}$<smiles>O=C(/C=C/c1ccc(O)c(O)c1)O[C@H]1C[C@](O)(C(=O)O)C[C@H](O)[C@H]1O</smiles>

Chlorogenic acid (CHL)<smiles>O=C(O[C@H]1Cc2c(O)cc(O)cc2O[C@H]1c1cc(O)c(O)c(O)c1)c1cc(O)c(O)c(O)c1</smiles>

Epigallocatechin-3-gallate (EGCg) 


\section{Results and Discussion}

\section{Isolation, structure elucidation, and semisynthetic analogs}

The combined extract of $\mathrm{CH}_{2} \mathrm{Cl}_{2} / \mathrm{MeOH}$ (1:1) and $\mathrm{MeOH}$ of air-dried twigs of $D$. barteri Bureau var. multiradiata having inhibitory activities on MMP-2 secretion in glioblastoma cells was further fractionated by silica gel column chromatography, followed by size exclusion chromatography over Sephadex LH-20. The post-chlorophyll fractions were combined and subjected to silica gel column chromatography and preparative TLC successively to afford: isobavachalcone (1), ${ }^{12}$ 4-hydroxylonchocarpin (2), ${ }^{10}$ kanzonol C (3), ${ }^{16}$ paratocarpin C (4), ${ }^{17}$, stipulin (5), ${ }^{6}$, and dorsmannin A (6) ${ }^{10}$ (Fig.1).<smiles>CC(C)=CCc1c(O)ccc(C(=O)/C=C/c2ccc(O)cc2)c1O</smiles><smiles>CC(C)=CCc1cc(/C=C/C(=O)c2ccc(O)c(CC=C(C)C)c2O)ccc1O</smiles><smiles>CC(C)=CCc1c(O)ccc(C(=O)/C=C/c2ccc3c(c2)C=CC(C)(C)O3)c1O</smiles><smiles>CC(C)=CCc1cc(/C=C/C(=O)c2cc(CC=C(C)C)c(O)cc2O)ccc1O</smiles><smiles>CC1(C)CCc2c(ccc(C(=O)/C=C/c3ccc(O)cc3)c2O)O1</smiles>

Figure 1. Natural prenylated chalcones (1-6) isolated from Dorstenia barteri Bureau var. multiradiata.

To further explore the structure-activity relationships of several modified chalcones about their capacity to inhibit MMP-2 secretion, kanzonol C (3) was converted into derivatives 7 and 8 under varied acid-catalyzed conditions ${ }^{17}$ (Scheme 1). Hence, treatment of $\mathbf{3}$ in methanolic $\mathrm{HCl}$ at reflux provided a mixture of cyclized derivatives 7 (cycloglabrol) and 8 (isocycloglabrol; artoindonesianin $\mathrm{J}$ ) in a ratio of $25 \%$ and $61 \%$, respectively (Scheme 1). When boron trifluoridediethyl etherate was used as acid catalyst, ${ }^{18}$ compound $\mathbf{8}^{19}$ was the only single isomer obtained in $83 \%$ yield (Scheme 1). Additionally, isobavachalcone 1 was transformed by hydrogenation into the dihydrochalcone derivative $\mathbf{9}^{20,21}$ in order to assess the importance of the double bonds on their biological activity (Scheme 2). 


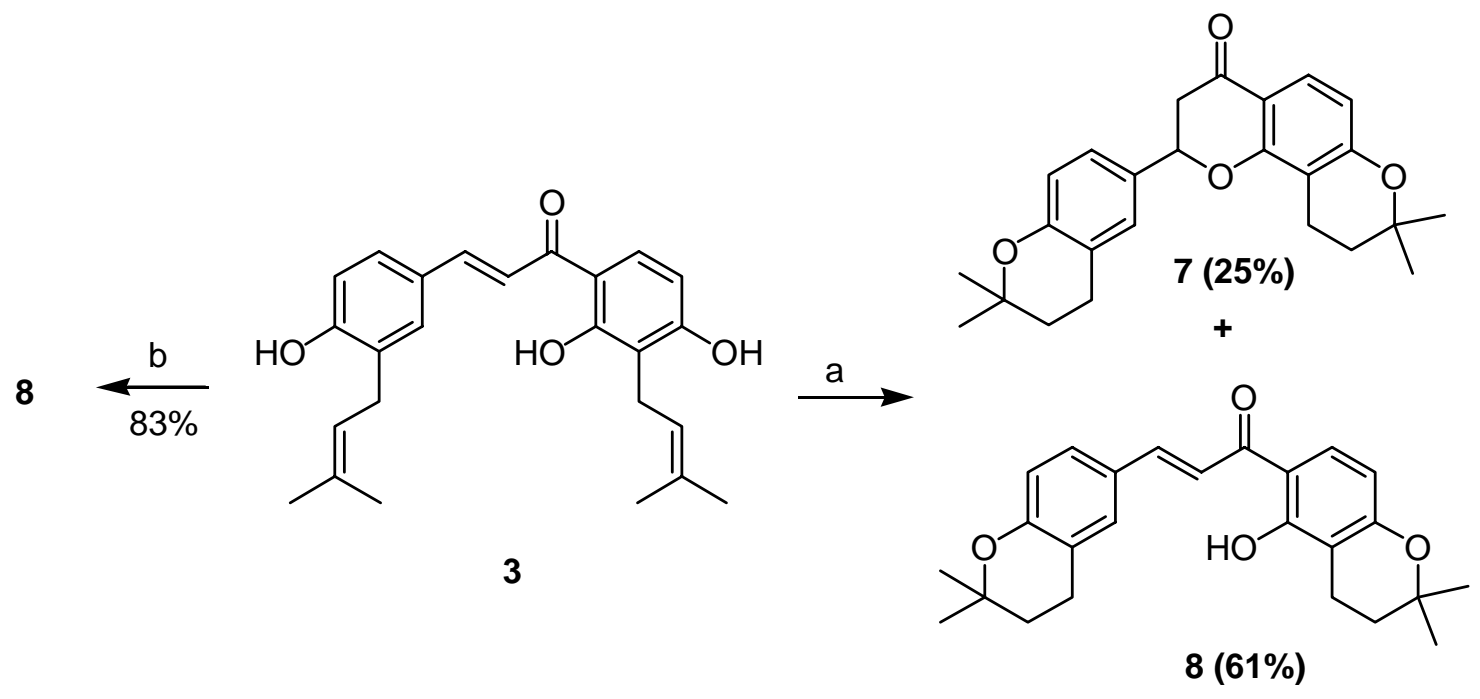

Scheme 1. Kanzonol C (3) acid-catalyzed cyclization: (a) $\mathrm{HCl}(36 \%)$ in $\mathrm{MeOH}$, reflux, 2 h; (b) $\mathrm{BF}_{3}-\mathrm{Et}_{2} \mathrm{O}, \mathrm{CH}_{2} \mathrm{Cl}_{2}, \mathrm{rt}, 2 \mathrm{~h}$.

The structures of the natural compounds (1-6) and their analogs (7-9) were determined on the basis of spectroscopic data (UV, IR, MS, ${ }^{1} \mathrm{H}$ NMR, and ${ }^{13} \mathrm{C}$ NMR). The known compounds 1-6, 8 were found identical to those previously described. ${ }^{6,10,12,16,17,19}$ Derivative 7 is described here for the first time as a new flavanone derivative. Compound $\mathbf{8}$ has been previously reported from the roots and tree bark of Artocarpus bracteata by Ersama et al. ${ }^{19}$<smiles>CCOC(=O)C(C)(C)CC(=O)c1ccc(O)c(CC=C(C)C)c1O</smiles>

Scheme 2. Isobavachalcone (1) hydrogenation.

Compound 9 has been synthesized previously as a testosterone $5 \alpha$-reductase inhibitor. ${ }^{21}$ There are no known studies on natural isobavachalcone $\mathbf{1}$ hydrogenation reported in the literature. The hydrogenated product 9 was isolated here for the first time via hemisynthesis by transformation of natural product $\mathbf{1}$ as a starting material. The structural identities of analogs $\mathbf{7 , 8}$, and 9 were fully established by ${ }^{1} \mathrm{H}-{ }^{1} \mathrm{H}$ COSY and HMBC experiments (Fig. 2 and 3). 


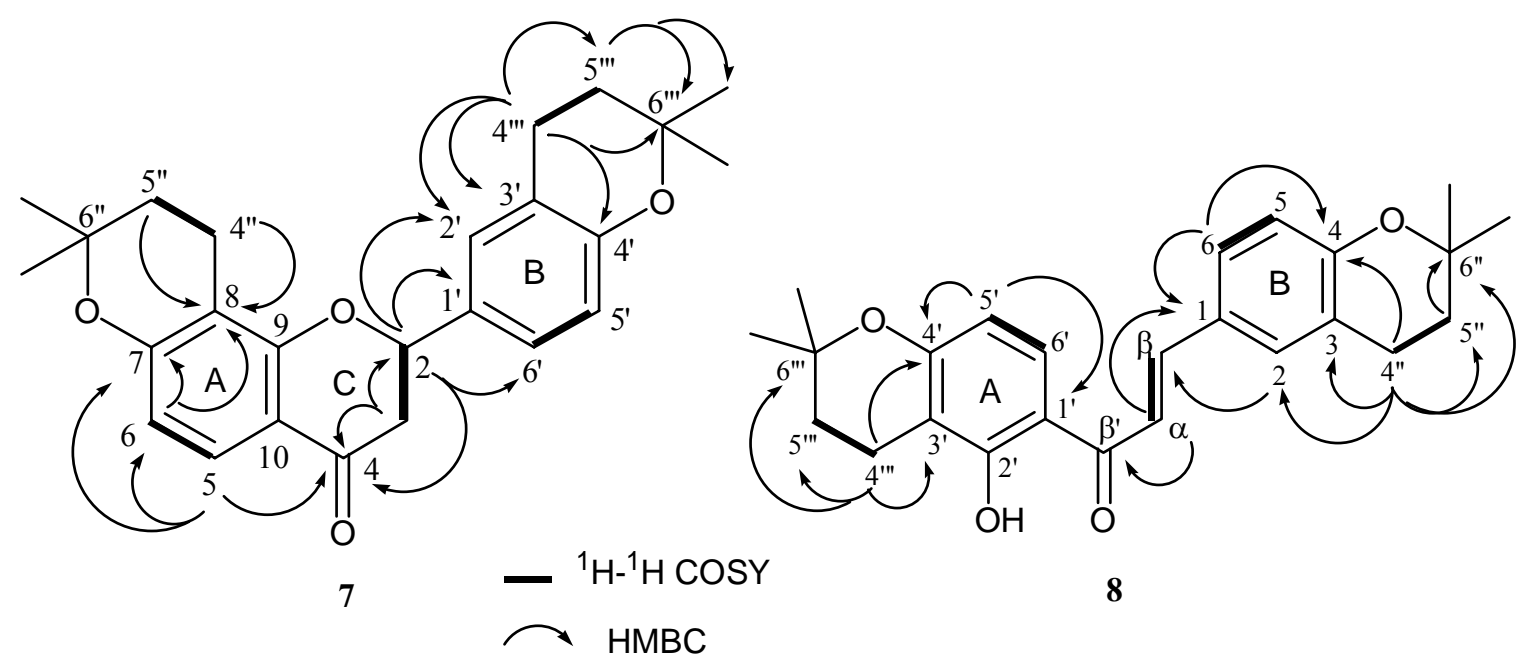

Figure 2. Selected ${ }^{1} \mathrm{H}-{ }^{1} \mathrm{H}$ COSY and HMBC correlations in kanzoflavanone (7) and compound 8, respectively.

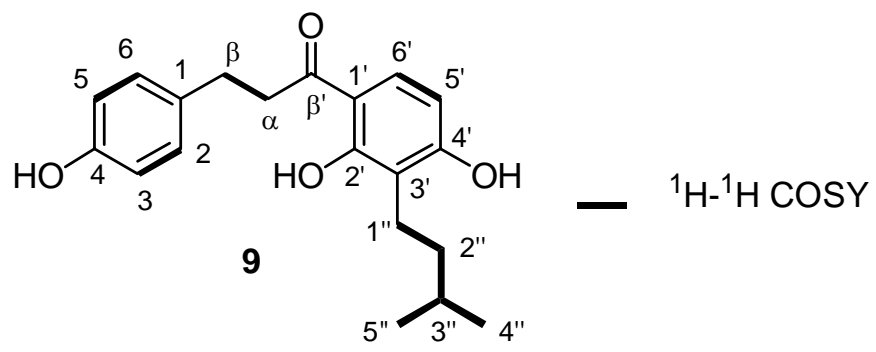

Figure 3. Selected ${ }^{1} \mathrm{H}-{ }^{1} \mathrm{H}$ COSY correlations in compound 9.

The genus Dorstenia (Moraceae) is represented by about 170 species worldwide. ${ }^{22}$ It contains several species commonly used in folk medicine for the treatment and/or management of an array of human disorders, including: arthritis, rheumatism, gout, stomach pain, cough and headache. ${ }^{23}$ To the best of our knowledge, no pharmacological studies have yet been made on this plant. While a previous phytochemical investigation of the same taxon afforded: 5,7,4'trihydroxy-8-prenylflavone, isobavachalcone (1), stipulin (5) and bichalcone, ${ }^{12}$ only isobavachalcone (1) and stipulin (5) were isolated again from this species in our study, and this variation observed in the chemical constitution may potentially be accounted for by the climatic condition, the period and area of plant collection.

\section{Inhibition of MMP-2 secretion in U87 glioblastoma cells}

The natural chalcones (1-6) isolated from D. barteri Bureau extracts and their synthetic analogs (7-9) were assayed for their ability to inhibit MMP-2 secretion in U87 glioblastoma cells using a gelatin zymography assay. The extent of gelatin hydrolysis by the MMP-2 secreted into the conditioned media upon treatment with the compounds tested was compared to that of known 
reference naturally occurring MMP secretion inhibitors CHL and EGCg (Fig. 4A). ${ }^{14,15}$ While cells remained adherent, indicative of very low cytotoxic effects of the treatments, all the natural chalcones (1-6) isolated from D. barteri Bureau species had moderate (20\%) to good (80\%) MMP-2 secretion inhibition ranging from $0.025 \mu \mathrm{M}$ to $250 \mu \mathrm{M}$ (Fig. 4B). These effects showed comparable potency of some of the compounds tested $(\mathbf{1}, \mathbf{4}, \mathbf{5}$, and $\mathbf{6})$ to that of CHL and EGCg (Fig.4B).

Comparing with hemisynthetic derivatives (7-9), natural compounds $\mathbf{1}, \mathbf{4}, \mathbf{5}$, and $\mathbf{6}$ were found more active on MMP-2 secretion inhibition and the maximum inhibitory effects ranged from $60-80 \%$ at $250 \mu \mathrm{M}$. The inhibitory activity of chalcones $\mathbf{1}$ and $\mathbf{3}$ tends to decrease when the prenyl group was hydrogenated or cyclized into benzopyrans to provide the analogs (7-9) since their activity was less potent than that of the corresponding prenylated chalcone precursors. This fact suggests that the prenyl and the hydroxyl groups on chalcone A or B ring was required for this series of compounds to show potent inhibition against MMP-2 secretion. With regards to the effects of the $\alpha, \beta$-unsaturated double bond of chalcone on activity, this conjugated system seems to enhance the activity of the chalcones. In fact, the hydrogenation of this double bond in compound 1 decreased the inhibition of MMP-2 secretion (Fig. 4B).

\section{A}

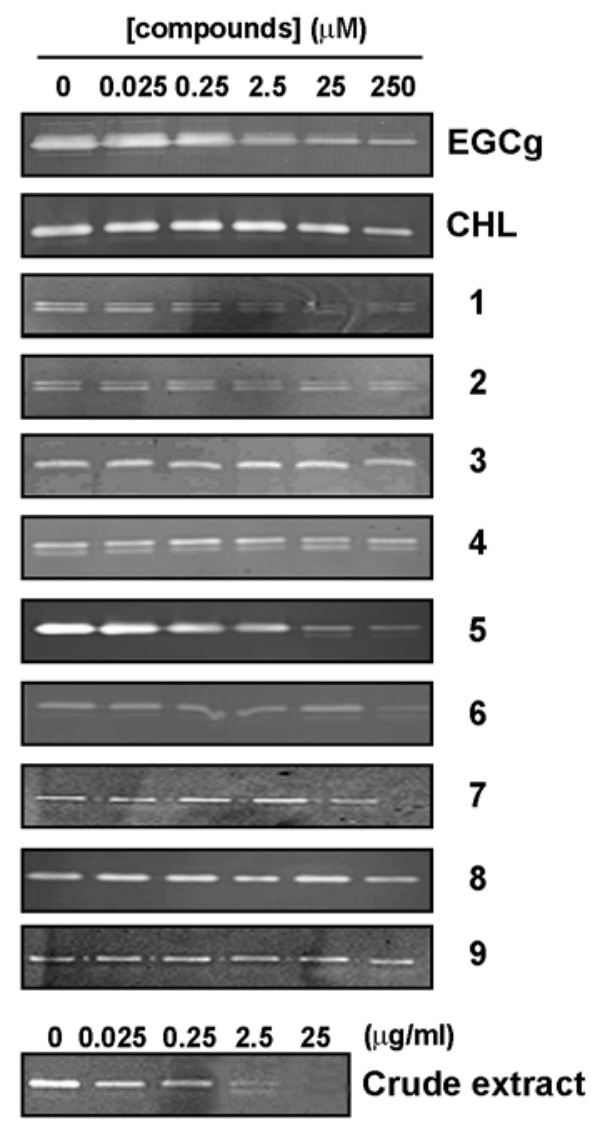




\section{B}

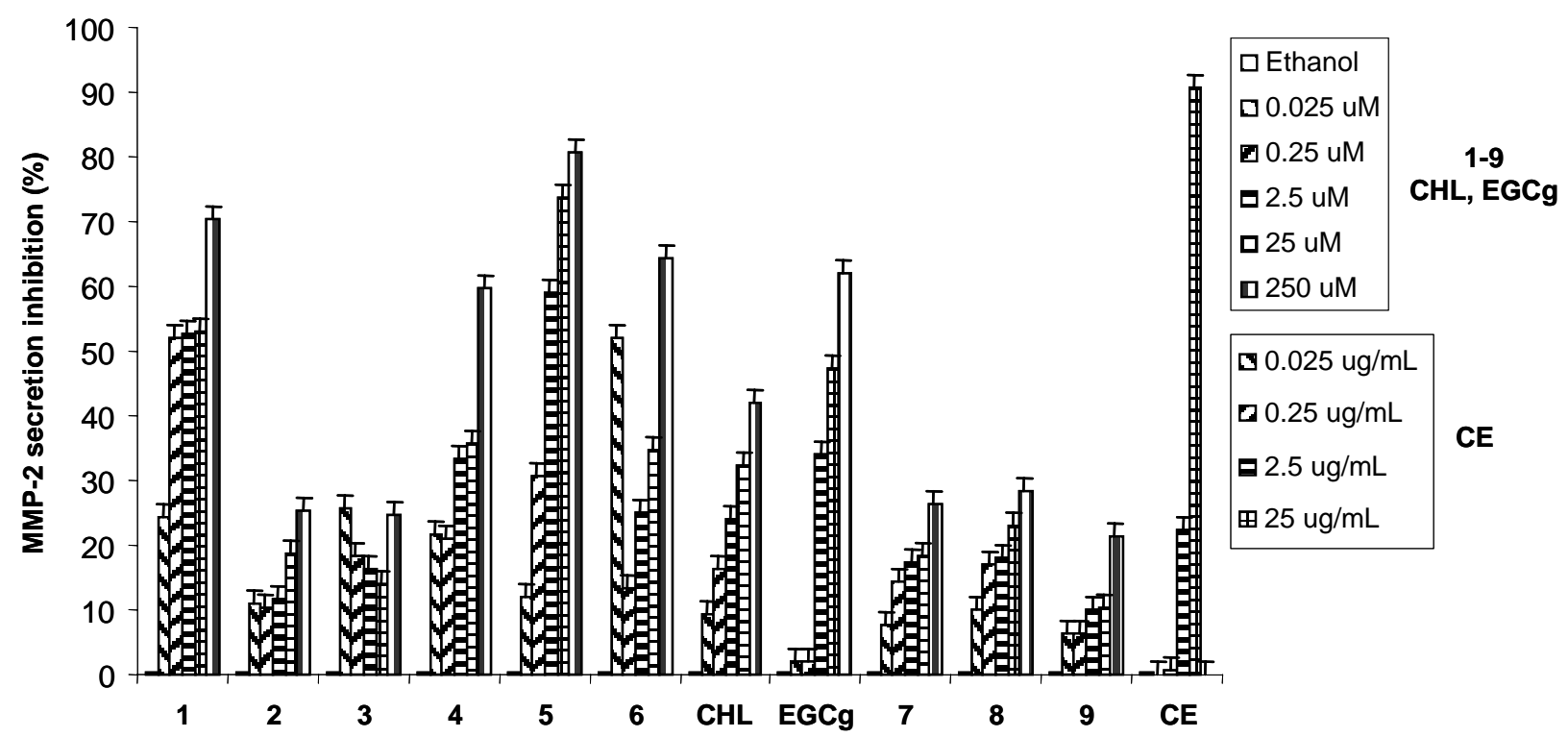

Figure 4. Effects of compounds (1- 9) and of the crude twig extract (CE) of Dorstenia barteri bureau on MMP-2 secretion from U87 glioblastoma cells. A) Representative gelatin zymography of media from U87 glioblastoma cells treated with increasing concentrations of compounds (1-9) and of crude extract. B) The bar graphs present the relative inhibitory effect of the compounds tested. The extent of gelatin hydrolysis was quantified by densitometry. Each value indicates the mean $\pm \mathrm{SD}$ from three experiments.

Brain tumor development is associated with extensive invasion into the surrounding brain tissue, and this infiltrative phenotype hampers efficient therapeutic interventions. Since MMP-2 is upregulated in glioblastomas, where its expression directly correlates with the invasive character of brain tumor cells and where it assists in extracellular matrix degradation and cancer cell movement, ${ }^{24,25}$ any elucidation of the anti-MMP secreting effects against brain tumor cells will help design and optimize current targeted therapeutic strategies. ${ }^{25}$ For instance, the MMP-2 secretion inhibitor green tea catechin EGCg has already been used to efficiently target the infiltrative and radioresistant phenotype of U87 glioblastoma cells. ${ }^{26,27}$ The present investigation demonstrates for the first time that prenylated chalcones isolated from the twigs of Dorstenia barteri Bureau appear to target MMP-2 secretion mechanisms from highly invasive brain tumorderived U87 glioblastoma cells. In fact, investigating the mechanisms involved in the inhibition of MMP-2 secretion will provide information that should allow antitumor evaluation of new synthetic derivatives of Dorstenia species. 
Table 1. ${ }^{1} \mathrm{H}(500 \mathrm{MHz})$ and ${ }^{13} \mathrm{C}$ NMR (125 MHz) spectral data, COSY, HMQC and important $\mathrm{HMBC}{ }^{2} \mathrm{~J},{ }^{3} \mathrm{~J}$-correlated carbons of kanzoflavanone (7) in $\mathrm{CDCl}_{3}$

\begin{tabular}{|c|c|c|c|c|c|}
\hline Position & $\delta \mathrm{H}$ & $\delta \mathrm{C}$ & $\begin{array}{c}\text { COSY } \\
\left({ }^{1} \mathrm{H}-{ }^{1} \mathrm{H}\right)\end{array}$ & HMQC & $\begin{array}{c}\text { HMBC } \\
{ }^{2} \mathrm{~J} \text { and }{ }^{3} \mathrm{~J} \text {-correlated } \\
\mathrm{C}{ }^{1} \mathrm{H} \rightarrow{ }^{13} \mathrm{C}\end{array}$ \\
\hline 2 & $5.37(\mathrm{dd}, \mathrm{J}=13.5,3.0)$ & 79.5 (d) & $3 a, 3 b$ & 79.5 & $4,1^{\prime}, 2^{\prime}, 6^{\prime}$ \\
\hline $3 a$ & $3.01(\mathrm{dd}, \mathrm{J}=16.5,13.5)$ & $44.1(\mathrm{t})$ & $2,3 b$ & 44.1 & 2,4 \\
\hline $3 b$ & $2.79(\mathrm{dd}, \mathrm{J}=16.5,3.0)$ & $44.1(\mathrm{t})$ & $2,3 \mathrm{a}$ & 44.1 & 4 \\
\hline $4(\mathrm{C}=\mathrm{O})$ & - & $191.4(\mathrm{~s})$ & - & - & - \\
\hline 5 & $7.73(\mathrm{~d}, \mathrm{~J}=9.0)$ & $125.7(d)$ & 6 & 125.7 & $4,6,7,9$ \\
\hline 6 & $6.50(\mathrm{~d}, \mathrm{~J}=8.5)$ & $111.8(\mathrm{~d})$ & 5 & 111.8 & $7,8,10$ \\
\hline 7 & - & $160.9(\mathrm{~s})$ & - & - & - \\
\hline 8 & - & $109.1(\mathrm{~s})$ & - & - & - \\
\hline 9 & - & $160.6(\mathrm{~s})$ & - & - & - \\
\hline 10 & - & $113.6(\mathrm{~s})$ & - & - & - \\
\hline 1 ' & - & $130.2(\mathrm{~s})$ & - & - & - \\
\hline 2 ' & 7.17 (br s) & $127.4(\mathrm{~d})$ & - & 127.4 & $2,4^{\prime}$ \\
\hline $3^{\prime}$ & - & $121.0(\mathrm{~s})$ & - & - & - \\
\hline $4^{\prime}$ & - & $154.3(\mathrm{~s})$ & - & - & - \\
\hline 5 & $6.83(\mathrm{~d}, \mathrm{~J}=8.5)$ & $117.4(\mathrm{~d})$ & 6 & 117.4 & $1^{\prime}, 3^{\prime}, 4^{\prime}$ \\
\hline 6 & $7.21(\mathrm{dd}, \mathrm{J}=8.5,2.0)$ & $125.4(d)$ & $5^{\prime}$ & 125.4 & $2,2^{\prime}, 4^{\prime}$ \\
\hline $4^{\prime \prime}$ & $2.69(\mathrm{q}$ like $\mathrm{m}, \mathrm{J}=6.8)$ & $16.8(\mathrm{t})$ & 5, & 16.8 & 8 \\
\hline 5, & $1.78(\mathrm{q}, \mathrm{J}=6.8)$ & $31.7(t)$ & 4, & 31.7 & 8 \\
\hline 6, & - & $74.5(\mathrm{~s})$ & - & - & - \\
\hline $4^{\prime \prime}$, & $2.82($ br t like $\mathrm{q}, \mathrm{J}=7.0)$ & $22.5(\mathrm{t})$ & $5,$, & 22.5 & $2^{\prime}, 3^{\prime}, 4^{\prime}, 5^{\prime \prime}, 6^{\prime \prime}$ \\
\hline 5, & $1.84(\mathrm{t}, \mathrm{J}=6.8)$ & $32.6(t)$ & $4, '$ & 32.6 & $3^{\prime}, 6^{\prime \prime}, 6^{\prime \prime}, \mathrm{Me}$ \\
\hline 6, & - & $75.5(\mathrm{~s})$ & - & - & \\
\hline 6' -Me & $1.36\left(2 \mathrm{xCH}_{3}\right.$, br s $)$ & $26,9(q) \times 2$ & - & 26.9 & - \\
\hline $6 \%,-\mathrm{Me}$ & $1.36(\mathrm{br} \mathrm{s})$ & $27.0(q)$ & - & 27.0 & $5, \%$ \\
\hline $6, ",-\mathrm{Me}$ & 1.34 (br s) & $26.3(q)$ & - & 26.3 & $5, \%$ \\
\hline
\end{tabular}

Multiplicities and coupling constant in $\mathrm{Hz}$ are given in parentheses. 
Table 2. $\quad{ }^{1} \mathrm{H}(500 \mathrm{MHz})$ and ${ }^{13} \mathrm{C}$ NMR $(125 \mathrm{MHz})$ spectral data, COSY, HMQC and important $\mathrm{HMBC}^{2} \mathrm{~J},{ }^{3} \mathrm{~J}$-correlated carbons of compound $\mathbf{8}$ in $\mathrm{CDCl}_{3}$

\begin{tabular}{|c|c|c|c|c|c|}
\hline Position & $\delta \mathrm{H}$ & $\delta \mathrm{C}$ & $\begin{array}{c}\text { COSY } \\
\left({ }^{1} \mathrm{H}^{1} \mathrm{H}\right)\end{array}$ & HMQC & $\begin{array}{c}\text { HMBC } \\
{ }^{2} \mathrm{~J} \text { and }{ }^{3} \mathrm{~J} \text {-correlated } \mathrm{C} \\
{ }^{1} \mathrm{H} \rightarrow{ }^{13} \mathrm{C}\end{array}$ \\
\hline 2 & 7.38 (br s) & $130.5(\mathrm{~d})$ & - & 130.5 & $4,6, \beta$ \\
\hline 3 & - & $121.3(\mathrm{~s})$ & - & - & - \\
\hline 4 & - & $156.7(\mathrm{~s})$ & - & - & \\
\hline 5 & $6.82(\mathrm{~d}, 8.5)$ & $117.4(\mathrm{~d})$ & 6 & 117.4 & $3,4,6$ \\
\hline 6 & $7.43(\mathrm{dd}, 8.5,2.0)$ & $127.9(\mathrm{~d})$ & 5 & 127.9 & 1,4 \\
\hline$\alpha$ & $7.46(\mathrm{~d}, 15.0)$ & $118.0(\mathrm{~d})$ & $\beta$ & 188.0 & $1, \beta^{\prime}$ \\
\hline$\beta$ & $7.83(\mathrm{~d}, 15.5)$ & $144.2(\mathrm{~d})$ & $\alpha$ & 144.2 & $2,6, \alpha, \beta^{\prime}$ \\
\hline $\begin{array}{c}\beta^{\prime} \\
(\mathrm{C}=\mathrm{O})\end{array}$ & - & $191.9(\mathrm{~s})$ & - & - & - \\
\hline 1 ' & - & $112.9(\mathrm{~s})$ & - & - & - \\
\hline 2'-OH & $14.00($ br s) & $160.5(\mathrm{~s})$ & - & - & - \\
\hline $3^{\prime}$ & - & $109.3(\mathrm{~s})$ & - & - & - \\
\hline $4^{\prime}$ & - & $164.0(\mathrm{~s})$ & - & - & - \\
\hline 5 & $6.38(\mathrm{~d}, \mathrm{~J}=9.5)$ & $109.0(\mathrm{~d})$ & 6 & 109.0 & $1^{\prime}, 3^{\prime}, 4^{\prime}$ \\
\hline 6 & $7.71(\mathrm{~d}, \mathrm{~J}=9.0)$ & $128.4(\mathrm{~d})$ & 5 & 125.4 & $\beta^{\prime}, 2^{\prime}, 4^{\prime}, 5^{\prime}$ \\
\hline 4, & $2.83(\mathrm{t}, \mathrm{J}=6.5)$ & $16.3(\mathrm{t})$ & 5, & 16.3 & $2,3,4,5^{\prime}, 6^{\prime \prime}$ \\
\hline 5, & $1.84(\mathrm{br} \mathrm{q}, \mathrm{J}=6.5)$ & $32.5(\mathrm{t})$ & $4 "$, & 32.5 & $4 ', 6 "$ \\
\hline 6, & - & $75.2(\mathrm{~s})$ & - & - & - \\
\hline $4, \%$ & $2.73(\mathrm{t}, \mathrm{J}=6.5)$ & $22.3(\mathrm{t})$ & $5,$, & 22.3 & $3^{\prime}, 4^{\prime}, 5^{\prime \prime}, 6^{\prime \prime}$ \\
\hline $5,$, & $1.84(\mathrm{br} \mathrm{q}, \mathrm{J}=6.5)$ & $31.8(\mathrm{t})$ & $4^{\prime,}$ & 31.8 & $3^{\prime}, 4^{\prime \prime}, 6^{\prime \prime \prime}-\mathrm{Me}$ \\
\hline $6^{\prime,}$ & - & $75.7(\mathrm{~s})$ & - & - & - \\
\hline $\mathrm{Me}_{2} \mathrm{C}$ & $1.37\left(4 \mathrm{xCH}_{3}, \mathrm{~s}\right)$ & $\begin{array}{c}26,7(q) \times \\
2 \\
27.9(q) \times 2 \\
\end{array}$ & - & $\begin{array}{l}26.7 \\
27.9\end{array}$ & 6, \\
\hline
\end{tabular}

Multiplicities and coupling constant in $\mathrm{Hz}$ are given in parentheses. 


\section{Experimental Section}

\section{General Procedures}

Instrumentation. Optical rotation was recorded on a Perkin-Elmer 241 polarimeter. UV spectra were measured on Varian Cary 1E spectrometer. IR spectra were recorded on a Nicolet Avatar 370 spectrometer with $\mathrm{CCl}_{4}$ solution. NMR spectra were obtained with a Bruker AMX-500 or on Varian Gemini-300 spectrometers. ESIMS were recorded on a Micromass Quattro LC mass spectrometer. Precoated silica gel plates (Merck, Kieselgel 60 F-254, $0.5 \mathrm{~mm}$ ) were used for PTLC. Thin layer chromatography (TLC) was performed on silica gel F254 (Merck) precoated aluminum sheets and spots were visualized under UV and by spraying with molybdenum solution and heating.

Cell culture. The U87 glioblastoma cell line was purchased from American Type Culture Collection and maintained in Eagle's Minimum essential medium (MEM) containing 10\% (v/v) fetal bovine serum (HyClone Laboratories, Logan, UT), $2 \mathrm{mM}$ glutamine, 100 units/ml penicillin and $100 \mu \mathrm{g} / \mathrm{ml}$ streptomycin. Cell culture was performed at $37^{\circ} \mathrm{C}$ under a humidified atmosphere containing $5 \% \mathrm{CO}_{2}$.

Gelatin zymography. To assess the extent of MMP-2 secretion in the conditioned media, gelatin zymography was used as described previously. ${ }^{15}$ Briefly, serum-starved U87 glioblastoma cells were treated with the appropriate compounds (1-9) for $18 \mathrm{hrs}$ at $37^{\circ} \mathrm{C}$ and an aliquot $(20 \mu \mathrm{l})$ of the culture medium was subjected to SDS-PAGE in gels containing $0.1 \mathrm{mg} / \mathrm{ml}$ gelatin. The gels were then incubated in $2.5 \%$ Triton $\mathrm{X}-100$ and rinsed in nanopure distilled $\mathrm{H}_{2} \mathrm{O}$. Gels were further incubated at $37^{\circ} \mathrm{C}$ for $20 \mathrm{hrs}$ in $20 \mathrm{mM} \mathrm{NaCl}, 5 \mathrm{mM} \mathrm{CaCl}_{2}, 0.02 \%$ Brij-35, $50 \mathrm{mM}$ Tris$\mathrm{HCl}$ buffer, $\mathrm{pH} 7.6$, then stained with $0.1 \%$ Coomassie Brilliant blue R-250 and destained in $10 \%$ acetic acid, $30 \% \mathrm{MeOH}$ in $\mathrm{H}_{2} \mathrm{O}$. Gelatinolytic activity was detected as unstained bands on a blue background.

Plant material. The twigs of D. barteri Bureau var. multiradiata were collected in March 2003 from Kumba, Cameroon, and identified by Mr. Victor Nana of the National Herbarium in Yaoundé, Cameroon where a voucher specimen (No. 44016HNC) was deposited.

Extraction and isolation. The air-dried and powdered twigs of D. barteri Bureau var. multiradiata $(1 \mathrm{~kg})$ were macerated in either a mixture of $\mathrm{CH}_{2} \mathrm{Cl}_{2} / \mathrm{MeOH}(1: 1)$ or in $\mathrm{MeOH}$ for 24 and $2 \mathrm{~h}$ respectively, at room temperature. The removal of solvent under reduced pressure yielded $45 \mathrm{~g}$ of dark green residues. A mass of $40 \mathrm{~g}$ of this organic extract was submitted to flash liquid chromatography on silica gel $60(220 \mathrm{~g})$ and eluted with hexane ethyl acetate solutions: $(3: 1),(1: 1),(1: 3)$, and finally with pure EtOAc to give 40 fractions of $250 \mathrm{ml}$ each. Fractions were monitored by TLC and fractions showing similar ${ }^{1} \mathrm{H}-\mathrm{NMR}$ spectra were combined. Fractions 1-20 (10 g), obtained with (7:3 v/v) hexane-EtOAc were subjected to column chromatography over silica gel using hexane-EtOAc as eluent with a continuous gradient (95:5 to $7: 3 \mathrm{v} / \mathrm{v}$ ), followed by gel filtration chromatography over Sephadex $\mathrm{LH}-20$ using $\mathrm{CHCl}_{3^{-}}$ $\mathrm{MeOH}(2: 1)$ as eluent. The post-chlorophyll fractions were combined and purified successively on column chromatography followed by preparative TLC to yield: isobavachalcone $\left(\mathbf{1}, 98 \mathrm{mg}, \mathrm{R}_{\mathrm{f}}\right.$ 
0.19, silica gel, hexane-EtOAc, 7:3 v/v) and stipulin $\left(5,20 \mathrm{mg}, \mathrm{R}_{\mathrm{f}} 0.40\right.$, silica gel, hexaneEtOAc, 3:1 v/v). Combined fractions 21-40 (25 g) obtained from the (1:1) to (1:3) hexaneEtOAc mixture and pure EtOAc were subjected successively to silica gel column chromatography and preparative TLC, eluting with solvent mixtures of increasing polarity, (from $\mathrm{CH}_{2} \mathrm{Cl}_{2}$ to $96: 4$ (v/v) $\left.\mathrm{CH}_{2} \mathrm{Cl}_{2}-\mathrm{MeOH}\right)$. Fractions eluted with $\mathrm{CH}_{2} \mathrm{Cl}_{2}$ gave, after repeated preparative TLC, 4-hydroxylonchocarpin (2, $45 \mathrm{mg}, \mathrm{R}_{\mathrm{f}}$ 0.37, silica gel, $\mathrm{CH}_{2} \mathrm{Cl}_{2}-\mathrm{MeOH}$ 98:2 v/v) and dorsmannin A $\left(6,15 \mathrm{mg}, \mathrm{R}_{\mathrm{f}}\right.$ 0.53, silica gel, $\mathrm{CH}_{2} \mathrm{Cl}_{2}-\mathrm{MeOH}$ 98:2 v/v); those eluted with $\mathrm{CH}_{2} \mathrm{Cl}_{2}-\mathrm{MeOH}$ (96:4) gave kanzonol C (3,125 mg, $\mathrm{R}_{\mathrm{f}}$ 0.27, silica gel, $\mathrm{CH}_{2} \mathrm{Cl}_{2}-\mathrm{MeOH}$ 97:3 v/v), and paratocarpin $\mathrm{C}\left(4,20 \mathrm{mg}, \mathrm{R}_{\mathrm{f}}\right.$ 0.46, silica gel, $\mathrm{CH}_{2} \mathrm{Cl}_{2}-\mathrm{MeOH}$ 97:3 v/v), after repeated PTLC. Chemical and materials. Cyclisation of kanzonol C (3). Method 1. A mixture of (3) (60 mg, $0.153 \mathrm{mmol})$ and $36 \% \mathrm{HCl}(12 \mathrm{ml})-\mathrm{MeOH}(40 \mathrm{ml})$ solution was refluxed for $2 \mathrm{~h}$. The reaction mixture was poured into water $(100 \mathrm{ml})$ and extracted with $\mathrm{CHCl}_{3}(4 \times 50 \mathrm{ml})$. The $\mathrm{CHCl}_{3}$ extract was washed with water, dried on $\mathrm{Na}_{2} \mathrm{SO}_{4}$ and evaporated under reduced pressure. The residue was separated and purified by PTLC, eluting with a solvent mixture of Hexane-EtOAc (8:2 v/v) to give compound (7) $\left(15,1 \mathrm{mg}, 0.039 \mathrm{mmol}, 25 \%, \mathrm{R}_{\mathrm{f}} 0.33\right.$, silica gel, hexane-EtOAc, 8:2 v/v) and $\mathbf{8}\left(36,3 \mathrm{mg}, 0.093 \mathrm{mmol}, 61 \%, \mathrm{R}_{\mathrm{f}}\right.$ 0.45, silica gel, hexane-EtOAc, 8:2 v/v).

Method 2. To a solution of $3(60 \mathrm{mg}, 0.153 \mathrm{mmol})$ in dry $\mathrm{CH}_{2} \mathrm{Cl}_{2}$ was added one drop of borontrifluoride diethyl etherate. The progress of the reaction was monitored by TLC. After 2 hours at $\mathrm{rt}$, the reaction mixture was diluted with EtOAc and washed with saturated aq. $\mathrm{NaHCO}_{3}(10 \mathrm{ml} \mathrm{x}$ 2 ). The organic phase was dried over $\mathrm{Na}_{2} \mathrm{SO}_{4}$ and concentrated under reduced pressure and the residue was purified by flash column chromatography on silica gel with a gradient of HexaneEtOAc (95:5 to 85:15 v/v) as eluent to provide 8 ( $49.8 \mathrm{mg}, 0.127 \mathrm{mmol}, 83 \%)$.

(+)-Kanzoflavanone (7) (cycloglabrol). Yellow oil; $[\alpha]^{25}+4.5^{\circ}(\mathrm{c}=1, \mathrm{MeOH})$; UV $\lambda \max ^{\mathrm{MeOH}}$ nm (log $\varepsilon$ ): 226 (3.46), 227 (3.46), 230 (3.47), 234 (3.47), 236 (3.47), 283 (3.45), 369 (2.36); $\lambda \max { }^{\mathrm{MeOH}+\mathrm{NaOAc}} \mathrm{nm}(\log \varepsilon)$ : no change; $\lambda \max { }^{\mathrm{MeOH}+\mathrm{NaOMe}} \mathrm{nm}(\log \varepsilon)$ : no change; IR $\left(\mathrm{CCl}_{4}\right) v_{\max }$ $\mathrm{cm}^{-1}:$ 2973-2852, $1680(\mathrm{C}=\mathrm{O}), 1601,1582,1499,1329,1231,1207,1157,1066,1018$; ESIMS $\mathrm{m} / \mathrm{z}$ (rel. int.): 393 [M+H] $]^{+}(100), 357$ (9), 261(8), 240 (13), 140(11), 105(17), 102(7); (calcd for $\left.\mathrm{C}_{25} \mathrm{H}_{28} \mathrm{O}_{4}, 392.48742\right) ;{ }^{1} \mathrm{H} \mathrm{NMR}$ spectral data $\left(500 \mathrm{MHz}, \mathrm{CDCl}_{3}\right) ;{ }^{13} \mathrm{C}\left(125 \mathrm{MHz}, \mathrm{CDCl}_{3}\right)$, COSY, HMQC and HMBC (Table 1).

Isocycloglabrol (8) (artoindonesianin J). ${ }^{19}$ Yellow oil; ESIMS m/z (rel. int.): 393 $[\mathrm{M}+\mathrm{H}]^{+}(100), 305$ (8), 261 (12), 217 (16), 173 (11); (calcd for $\mathrm{C}_{25} \mathrm{H}_{28} \mathrm{O}_{4}, 392.48742$ ); ${ }^{1} \mathrm{H}$ NMR spectral data $\left(500 \mathrm{MHz}, \mathrm{CDCl}_{3}\right) ;{ }^{13} \mathrm{C}\left(125 \mathrm{MHz}, \mathrm{CDCl}_{3}\right)$, COSY, HMQC and HMBC (Table 2).

Hydrogenation of isobavachalcone (1). A solution of 1 (38.9 $\mathrm{mg}, 0.12 \mathrm{mmol})$ in ethanol (8 $\mathrm{ml})$ was hydrogenated in the presence of $10 \%$ of Palladium on charcoal $(10 \mathrm{mg})$ at room temperature. The reaction was monitored by TLC until completion (40 min) and the catalyst was removed by celite gel filtration. The filtrate was evaporated in-vacuum and purified by chromatography over PTLC on silica-gel using a mixture of hexane- EtOAc $(7: 3 \mathrm{v} / \mathrm{v})$ as eluant to afford crude product $9\left(30.6 \mathrm{mg}, 0.094 \mathrm{mmol}, 78 \%, \mathrm{R}_{\mathrm{f}} 0.30\right.$, silica gel, hexane-EtOAc, 7:3 v/v). 2', 3', ,, $\boldsymbol{\beta}$-Tetrahydro-isobavachalcone (9). ${ }^{21}$ Colourless oil, ESIMS m/z (rel. int.): 329 $[\mathrm{M}+\mathrm{H}]^{+}(100), 305$ (19), 261 (49), 239 (14), 217 (39), 171 (50), 157 (56), 148 (18), 105 (12); 
(calcd for $\left.\mathrm{C}_{20} \mathrm{H}_{24} \mathrm{O}_{4}, 328.4056\right) ;{ }^{1} \mathrm{H}$ NMR $\left(300 \mathrm{MHz}, \mathrm{CD}_{3} \mathrm{COCD}_{3}\right) \delta: 0.93$ and $0.95(3 \mathrm{H}$ each, s, $2 \times \mathrm{Me}), 1.41(2 \mathrm{H}, \mathrm{q}, \mathrm{J}=7.8 \mathrm{~Hz}, 2 \mathrm{H}-2$ ' ') 1.57 (m, H-3' '), 2.66 (2H, t, J = 7.8 Hz, 2H-1' '), 2.92 $(2 \mathrm{H}, \mathrm{t}, \mathrm{J}=7.5 \mathrm{~Hz}, 2 \mathrm{H}-\beta), 3.23(2 \mathrm{H}, \mathrm{t}, \mathrm{J}=7.5 \mathrm{~Hz}, 2 \mathrm{H}-\alpha), 6.47$ (d, J = 9.0 Hz, H-5'), 6.75 ( 2H, d, J $=8.4 \mathrm{~Hz}, \mathrm{H}-3, \mathrm{H}-5), 7.11(2 \mathrm{H}, \mathrm{d}, \mathrm{J}=8.4 \mathrm{~Hz}, \mathrm{H}-2, \mathrm{H}-6), 7.66$ (d, J = 9.0 Hz, H-6'), 13.17 (s, 2'$\mathrm{OH}) ;{ }^{13} \mathrm{C}\left(75 \mathrm{MHz}, \mathrm{CD}_{3} \mathrm{COCD}_{3}\right) \delta: 204.5$ (s, C- $\beta^{\prime}$ ), 163.3 (s, C-4'), 162.1 (s, C-2'), 155.8 (s, C-4), 132.1 (s, C-1), 129.6 (d, C-2, C-6), 129.4 (d, C-6'), 116.5 (d, C-3, C-5), 115.3 (s, C-1'), 113.0 (s, C-3'), 107.4 (d, C-5'), 39.7 (t, C- $\alpha$ ), 37.9 (t, C-2'’'), 29.8 (t, C- $\beta$ ), 28.3 (d, C-3' '), 22.2 (q, 2xMe), 20.3 (t, C-1 ${ }^{\prime}$ ); ${ }^{1} \mathrm{H}-{ }^{1} \mathrm{H}$ COSY (Fig. 3).

\section{Acknowledgements}

$\mathrm{BN}$ is grateful to the AUF, NSERC and CRC for a travel grant to the Department of Chemistry, Université du Québec à Montréal (Canada). RR and BA acknowledge financial support from the Natural Sciences and Engineering Research Council of Canada (NSERC) for a Canadian Research Chair in Therapeutic Chemistry and a Canadian Research Chair in Molecular Oncology, respectively.

\section{References and Footnotes}

1. Cragg, G. M.; Newman D. J. Expert Opin. Investig. Drugs 2000, 9, 2783.

2. Go, M. L.; Wu, X.; Liu, X. L. Curr. Med. Chem. 2005, 12, 483.

3. Middleton, Jr., E.; Kandaswami, C.; Theoharides, T. C. Pharmacol. Rev. 2000, 52, 673.

4. Tahara, S.; Katagiri, Y.; Ingham, J. L.; Mizutani, J. Phytochemistry 1994, 36, 1261.

5. Amoros, M.; Simoes, C. M. O.; Girre, L.; Sauvager, F.; Cormier, M. J. Nat. Prod. 1992, 55, 1732.

6. Abegaz, B. M.; Ngadjui, T. B.; Dongo, E.; Tamboue, H. Phytochemistry 1998, 49, 1147.

7. Gerhauser, C.; Alt, A.; Heiss, E.; Eldeen, A. G.; Klimo, K.; Knauft, J.; Neumann, I.; Scherf, H. R.; Frank, N.; Bartsch, H.; Becker, H. Mol. Cancer Therap. 2002, 1, 959.

8. Mukherjee, S.; Kumar, V.; Prasad, A. K.; Raj, H. G.; Bracke, M. E.; Olsen, C. E.; Jain S. C.; Parmar, V. S. Bioorg. Med. Chem. 2001, 9, 337.

9. Nagao, T.; Abe, F.; Kinjo, J.; Okabe, H. Biol. Pharm. Bull. 2002, 25, 875.

10. Ngadjui, T. B.; Kouam, F. S.; Dongo E.; Kapche, F. W. G.; Abegaz, M. B. Phytochemistry 2000, 55, 915.

11. De Vincenzo, R.; Scambia, G.; Panici, P. B.; Ranelletti, F. O.; Bonanno, G.; Ercoli, A.; Delle M. F.; Ferrari, F.; Piantelli, M.; Mancuso, S. Anti-Cancer Drug Design 1995, 10, 481.

12. Tsopmo, A.; Tene, M.; Kamnaing, P.; Ayafor, J. F.; Sterner, O. J. Nat. Prod. 1999, 62, 1432. 
13. Akihisa, T.; Tokuda, H.; Hasegawa, D.; Ukiya, M.; Kimura, Y.; Enjo, F.; Suzuki T.; Nishino, H. J. Nat. Prod. 2006, 69, 38.

14. Annabi, B.; Lachambre, M. P.; Bousquet-Gagnon, N.; Page, M.; Gingras, D.; Beliveau, R. Biochim.Biophys. Acta 2002, 1542, 209.

15. Belkaid, A.; Currie, J.C.; Desgagnés, J.; Annabi, B. Cancer Cell Internat. 2006, 6, 7.

16. Fukai, T.; Nishizawa, J.; Nomura, T. Phytochemistry 1994, 5, 515.

17. Hano Y.; Itoh N.; Hanaoka A.; Nomura T. Heterocycles 1995, 41, 2313.

18. Toepfer A.; Schmidt R. R. J. Carbohydr. Chem. 1993, 12, 809.

19. Ersama, T.; Achmada, S. A.; Ghisalberti, E. L.; Hakima, E. H.; Makmur, L.; Syah, Y. M. J. Chem. Res. Synop. 2002, 4, 186.

20. Liu, X.; Go, M.-L. Bioorg. Med. Chem. 2006, 14, 153.

21. Sato, S.; Yanagisawa, T.; Chin, M.; Hosaka, K. Patent JP 01125320, 1989; p 17.

22. Mabberley, D. J. The Plant Book, Cambridge University Press: Cambridge, 1987; p 192.

23. Abegaz, B. M.; Ngadjui, B. T.; Dongo, E.; Bezabih, M. T. Curr. Org. Chem. 2000, 4, 1079.

24. Deryugina, E.I.; Bourdon, M.A.; Luo, G.X.; Reisfeld, R.A.; Strongin, A. J Cell Sci. 1997, $110,2473$.

25. Nakada, M.; Okada, Y.; Yamashita, J. Front Biosci. 2003, 8, e261.

26. Annabi, B.; Bouzeghrane, M.; Moumdjian, R.; Moghrabi, A.; Beliveau, R. J Neurochem. 2005, 94, 906.

27. McLaughlin, N.; Annabi, B.; Bouzeghrane, M.; Temme, A.; Bahary, J.P.; Moumdjian, R.; Beliveau, R. Brain Res. 2006, 1071, 1. 